\title{
THE FATHER OF BULGARIAN LITERATURE, IVAN VAZOV ${ }^{1}$
}

Abstract:

The article discusses Ivan Vazov (1850-1921), the father of Bulgarian literature, poet, novelist, playwright, one of the creators of the modern Bulgarian literary language. He was the chief creative figure of the Bulgarian national revival era and the several subsequent decades, the creator of the first Bulgarian novel Under the Yoke, one of the pillars of Bulgarian national theatre. Vazov became a chronicler of his era, making it possible to study the history of Bulgaria through his work. During the life of the writer, Bulgaria managed to throw off the five-century Ottoman yoke following the RussoTurkish war of 1877-78. This made him a russophile, for which he was persecuted by the Bulgarian authorities, who soon after the liberation of the country took a pro-Western position. Vazov's work belongs not only to Bulgarian literature, but also to world literature. His works have been translated into 52 foreign languages.

\section{Keywords:}

Ivan Vazov, Encyclopedia, literary chronicler, pioneer, Russophilia, novel Under the Yoke.

АННОТацИя: М.Г. СмОЛЬЯНИНОВА. «ПАТРИАРХ БОЛГАРСКОЙ ЛИТЕРАТУРЫ ИВАН ВАЗОВ».

В статье говорится об Иване Вазове (1850-1921), патриархе болгарской литературы, поэте, прозаике, драматурге, одном из создателей современного болгарского литературного языка. Он являлся крупнейшей творческой фигурой эпохи Болгарского национального возрождения и нескольких последующих десятилетий, создателем первого болгарского романа «Под игом», одним из столпов болгарского национального театра. Вазов стал летописцем своей эпохи, по его произведениям можно изучать историю Болгарии, которая при жизни писателя сумела избавиться от пятивекового османского ига благодаря освободительной русско-турецкой войне 1877-78 гг. Это сделало его русофилом, за что он пострадал от болгарских властей, которые вскоре после освобождения страны заняли прозападную позицию. Творчество Вазова принадлежит не только болгарской, но и мировой литературе. Его произведения переведены на 52 иностранных языка.

\section{Ключевые слова:}

Энциклопедичность, патриарх, «летописец», «первопроходец», русофильство, роман «Под игом».

$\mathrm{I}$ van Vazov was a Bulgarian poet, prose writer, playwright, whose works have been translated into 52 world languages. Honorary Member of the Bulgarian Academy of Sciences (1921), Honorary Doctor of Philology, Sofia University (1921). Born in Sopot into the family of a merchant, he studied at a school in his hometown and later at a gymnasium in Plovdiv. In 1875 he took

\footnotetext{
1 The work was carried out with the financial support of the RFBR (grant № 18-512-76004).
} 
part in the work of a Secret Revolutionary Committee in Sopot, which set as its goal the national liberation of Bulgaria. In 1876-77 he lived in exile in Romania, where he became a member of the Bulgarian Charity Society. During the Russo-Turkish War of liberation (1877-78), he served in the Russian army as a special duty officer. After Bulgaria's liberation from the Ottoman yoke, he lived in Plovdiv, where he was a member of the Standing Committee of the Regional Assembly (1880-85). At the time of the Stambolov regime, he was persecuted for his Russophile convictions and emigrated to Odessa (1887-89). He was the people's representative in the VIII and IX National Assembly (189499) and the Minister of Education (1897-98).

Vazov began to publish in 1870 .

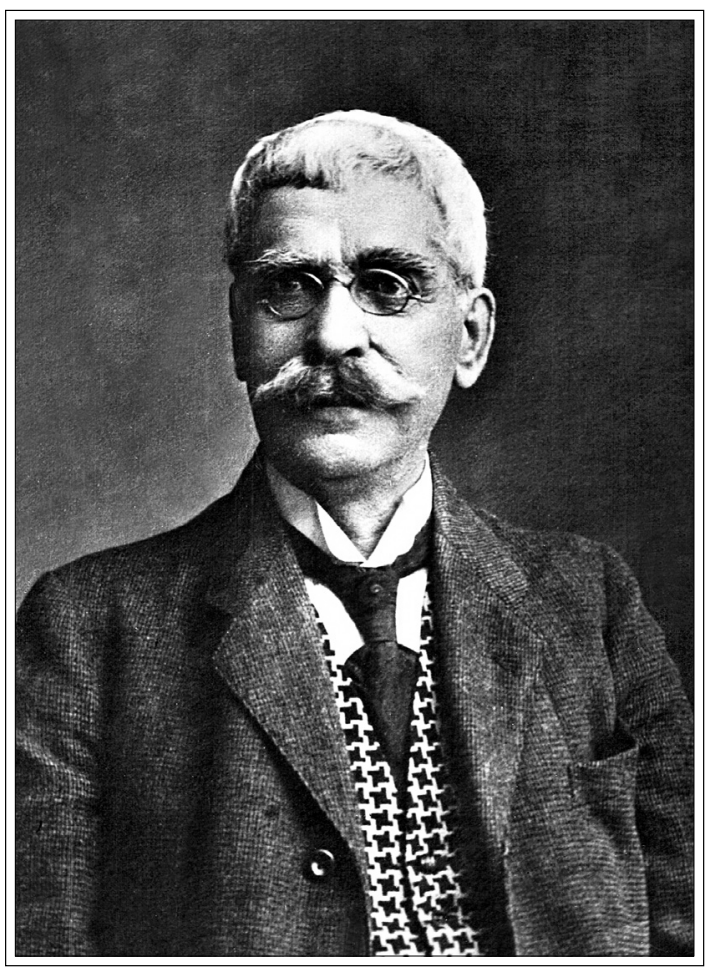

Ivan Vazov.

Photo of the last years of the writer's life The poem Pine ("Periodical Journal," 1871) and three collections of poetry published in Romania in the 1870 s brought him fame. The first of them, The Banner and The Harp (1876), reflected the Bulgarian people's upsurge of patriotism during the final stage of the national liberation struggle on the eve of and during the April uprising against the Turks in 1876. Many of the collection's poems called for the overthrow of Ottoman tyranny and glorified the heroism and self-sacrifice of the fighters who fought for Bulgaria's independence (Freedom or Death, Banner, Avenger, Radetsky). The hero of these works is a romantic "avenger" (in the spirit of folk songs), a patriot ready to die for the freedom of the motherland. The heroes of individual poems actually merge with a lyrical image of the author himself. The poet recalled: "The revolutionary movement began in 1875. At that time, under the influence of new revolutionary ideas and poems by Botev and Stambolov, I began to write rebellious songs, most of which were later included in the collection The Banner and the Harp. One poem, The Battle Rages, printed under the title Song of the Panagyur Rebels, became very popular during the April uprising and was sung throughout Bulgaria. Vazov connected faith in the imminent liberation of the motherland with an idea that was infinitely dear to him: that of a pan-Slavic brotherhood, with the hope of help from Russia. 
In the poetry collection The Sorrows of Bulgaria (1877), Vazov, with pain and anger, condemned the atrocities of the Turks who had put down the April uprising of 1876, massacring the population of Batak, burning many villages and towns to the ground, and killing thousands of children, women and elderly. Vazov called the Ottoman yoke "Hellish torments" and "Golgotha," and called on Russia to help his compatriots. In the poem Russia, written in November 1876, five months before the start of the Russo-Turkish war of liberation, Vazov appealed for help and wrote that the Bulgarians were waiting for Russia as a messiah; Russia responded to Bulgaria's sobs and cries. On 12 April 1877, Emperor Alexander II declared war on Turkey. At the cost of enormous human sacrifice, the Russian people liberated Bulgaria from five centuries of slavery.

The final collection of the poetic trilogy, The Deliverance (1878), expresses the jubilation of the Bulgarian people and their gratitude to the Russians for liberating Bulgaria. The poems Pleven fell, Guns thundered and others sing of the glory of Russian arms. The poet devotes a series of poems to members of the imperial family. In Ode to Emperor Alexander II, written on the occasion of the triumphal entry of the tsar to Bucharest in June 1877, the poet, in a classical vein, glorifies the hero, who goes into battle not to enslave Bulgaria but to liberate it. He compares the Russian emperor with the sun, radiating hope and incinerating the chains of slavery. While the odes dedicated to the members of the imperial family are stately and solemn, then Vazov's poems about the dead Russian soldiers are filled with pain and compassion.

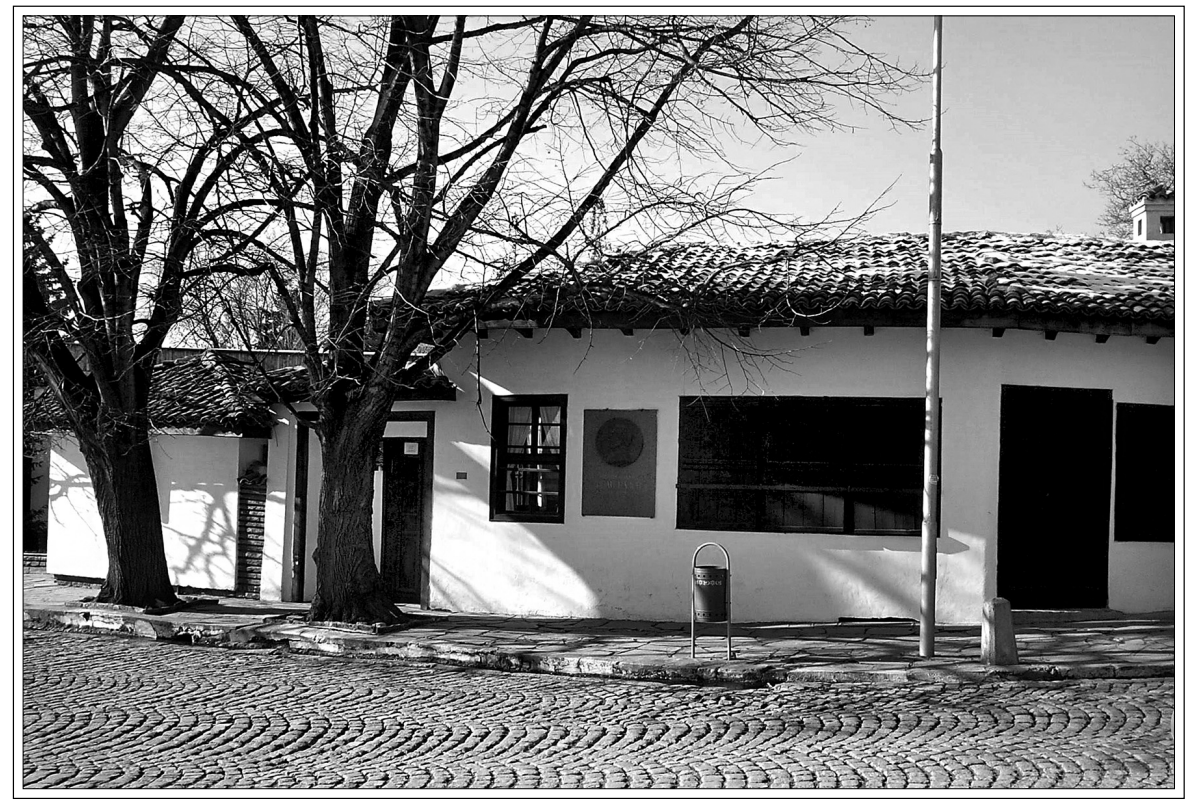

The house-museum of Ivan Vazov in Sopot, where be was born 
Vazov's works reflect universal ideas of Christianity (about good and evil in this world, Christian culture, and the relationship between God and man). Vazov believed that Bulgaria's liberation by the Russians was God's providence. In the poem Hello, Brothers, the mother tells her son about the Russians: "God himself sent them, // To help us, son." The works of Vazov not only deliver aesthetic pleasure, but are also an artistic chronicle of national history. Vazov called the Russian soldiers "knights of good."

After the Bulgaria's liberation from the Turkish yoke, Vazov wrote in the 1880s a cycle of short lyrical epic poems, Epic of the Forgotten (1881-84), devoted to figures of the national revival (Paisius of Hilendar, Georgy Rakovsky, the Miladinov brothers, Vasil Levski, etc.), emerging as the pinnacle of patriotic poetry.

During this period, the poems Gramada (1880), Trayko and Reese (1881), Zagorka (1883), The Realm of Mermaids (1884) and others were written. In 1881 Vazov published in journal "The Science" in Plovdiv his memories on the April uprising, The Recent, marking the birth of Vazov as a prose writer (in the previous decade, he wrote only as a poet).

In the 1880s he published the poems Gusli (1881), Fields and Forests (1884), Italy (1884) and Slivnitsa (1886). His lyrics differed in their thematic and genre diversity. Poetic depictions of Bulgarian nature alternate in these books with sharp satire on modern society. In 1889 the collection Songs of a Wanderer (1899) was published and in 1900 Under Our Sky. Many of the poems in these

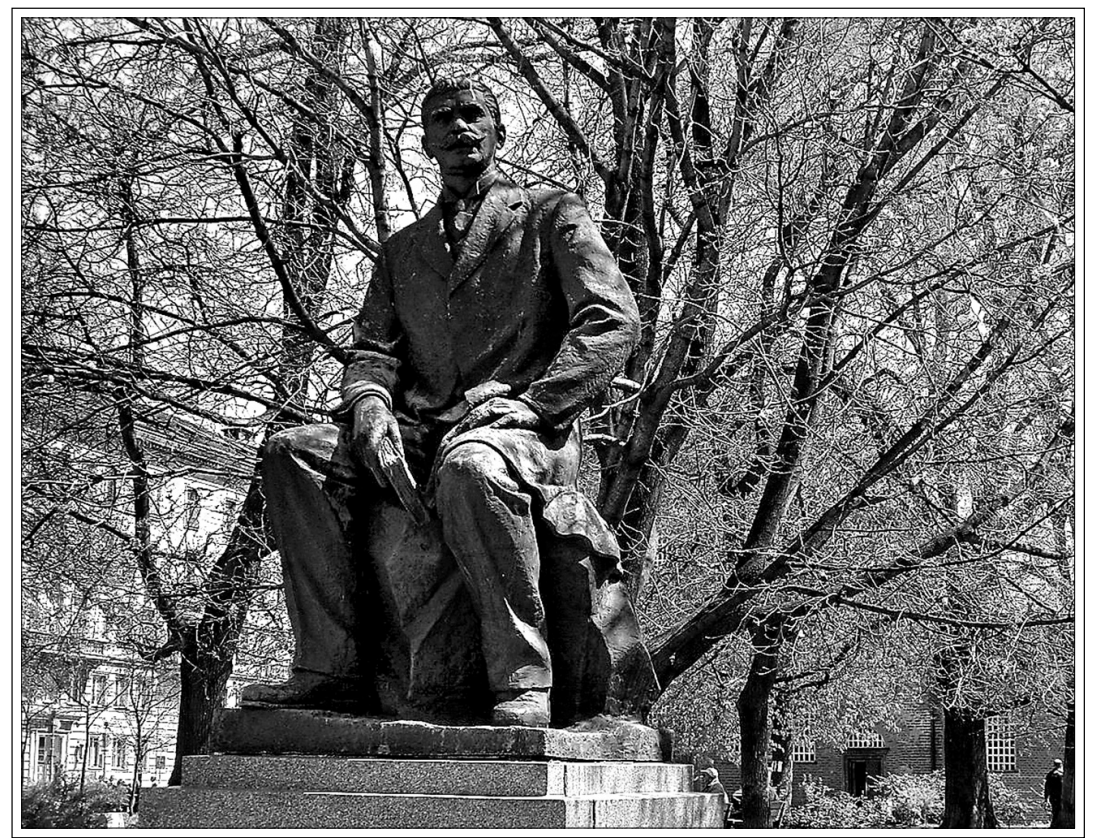

Monument to Ivan Vazov in Sofia 
books are devoted to the harsh fate of Bulgarian peasantry. Vazov's prose initially relied on the author's memoirs, recreating life of the final years of slavery. In his first short story, Mitrophan and Dormidolsky (1881), the writer used impressions of life in Berkovitsa. In 1885 the story Our Kin was published, which humorously depicted life in a Bulgarian province on the eve of the war of liberation. By the 1880 s he had already created works that were considered to be classics of Bulgarian literature: the story The Miserable Ones (1883-84), dedicated to the life of Bulgarian emigrants in Romania, and the novel Under the Yoke (1889-90). This novel was published five times in Bulgaria during the writer's lifetime, was translated into many languages and became a sensation not only in Bulgarian, but also in world literature. Vazov did not rely on historical documents in the novel, and there were no depictions of historical personages in it (in contrast to Epic of the Forgotten). Yet this novel, which portrayed the main historical process of the national revival, the transformation of peaceful Bulgarians into rebels fighting for the freedom of their homeland, was a broad epic canvas, depicting the lives of the Bulgarian people during their final years of slavery. For the first time in Bulgarian literature, the people were portrayed as the conscious driving force of the liberation movement. The novel is a testament to the artistic mastery of the writer, who was able to imbue everyday life with the breath of history and to convey the spirit of the revolutionary era.

Translated by Ksenia Melchakova

\section{BIBLIOGRAPHY}

Tsaneva M. Patriarhat: Etyudi varhu tvorchestvoto na Ivan Vazov. Sofia, 2000.

Velchev V. Ivan Vazov. Zhiznen i tvorcheski pat. Sofia, 2005.

\section{ILLUSTRATIONS}

1. Ivan Vazov. Photo of the last years of the writer's life.

2. The house-museum of Ivan Vazov in Sopot, where he was born.

3. The house-museum of Ivan Vazov in Berkovitsa.

4. Ivan Vazov in his office in his own house on the street. G. Rakovsky in Sofia. 1895.

5. The house-museum of Ivan Vazov in Sofia on the street. G. Rakovsky.

6. Muse of the writer, Eugene Mars (1877-1945).

7. The grave of Ivan Vazov near the church of St Sophia. The boulder for his grave was brought from Vitosha, where he liked to walk.

8. Monument to Ivan Vazov in Sofia.

9. National Drama Theater named after Ivan Vazov in Sofia.

10. Works of Ivan Vazov in 6 volumes, translated into Russian. Moscow, 1956. 